\section{International Scientific Journal Theoretical \& Applied Science}

p-ISSN: 2308-4944 (print)

e-ISSN: 2409-0085 (online)

Year: 2015

Issue: 02

Volume: 2

Published: 28.02.2015

http://www.T-Science.org

\author{
Nishiaki Yoshihiro \\ Ph.D. \\ professor of the University Museum \\ University of Tokyo, \\ Tokyo, Japan
}

Elnur Latif oglu Hasanov Corresponding member of International Academy of Theoretical and Applied Sciences, $\mathrm{Ph} . \mathrm{D}$. postgraduate Institute of Local-lore of Ganja Branch Azerbaijan National Academy of Sciences, Ganja, Azerbaijan 1-hasan@hotmail.com

\title{
INNOVATIVE ARGUMENTS ON RESEARCH OF SOME LOCAL CRAFTSMANSHIP BRANCHES AND PREHISTORIC MONUMENTS OF GANJA
}

\begin{abstract}
On the basis of innovative arguments and new scientific methods in this work for the first time have been researched the basic typical features of local craftsmanship branches and prehistoric monuments of Ganja. History of ethnographic-archaeological studying of these monuments and the main handicraft patterns also were investigated.

Key words: Azerbaijan, Ganja, prehistoric monuments, innovative methods and technologies, craftsmanship branches and local patterns.

Language: English

Citation: Yoshihiro N, Hasanov EL (2015) INNOVATIVE ARGUMENTS ON RESEARCH OF SOME LOCAL CRAFTSMANSHIP BRANCHES AND PREHISTORIC MONUMENTS OF GANJA. ISJ Theoretical \& Applied Science 02 (22): 11-15. doi: http://dx.doi.org/10.15863/TAS.2015.02.22.3
\end{abstract}

\section{Introduction}

During the archeological excavations materialcultural remains have proved that Ganja, which is one of humanity's most ancient settlements, had played an important role in the history of the development of science and culture of our country. During passage point of Zoroastrian, moslim, and christian civilization, also location on the Silk Way from West to East, from North to South,suitable natural-geografical conditions, rich soil, mild climate, plentiful rivers, also talented and gifted people of Ganja played exceptional role for developing in Azerbaijan science and culture history. Ganja is located on the ancient caravan routes, so merchants, travelers, scientists and cultural workers from different countries of the world visited Ganja, and first of all, their visiting helped our nation to integrate their spiritual values to all mankind civilizations. Also in XI century, during the Arab Caliphate flowering, the great thinker Gatran Tabrizi's population in Ganja shows, that Ganja has become a major center of culture and science in the Muslim East. From the sources it becomes clear, in that period in Ganja there were personal and public libraries, medresses as modern universities, observatories and medical centers. Muslim culture has spread to the neighboring Christian states from here. That why, many scientists, poets, architects, artists from different countries of East settled in Ganja. Also, Sheikh Nizami, appreciating Ganja's cultural level more highly, praised his native city "My Babil". In the middle of the XII century there were schools, medresses, private and public libraries, "The houses of wisdom" and "Health centers» in Ganja. In historical sources there was information that, in Ganja there was a large library "Dar al-kutub" that had been led by a famous scientist Abulfaz al-Nakhchivani. From Sheikh Nizami's reading and the names of the works, it becomes clear, that there were rich libraries in Ganja. Thus, about this regard the Sheikh of the Sheikhs says:

I said that I must create the work

And decorate it with tender ornaments.

All the book in world

I tried and found them.

I read and read

Works on arabian, bukhari, teberi and dari,

And I found pearls in every treasure,

From time to time from every paper

I tied samples

Then, I tided my thoughts up,

And wanted to write epos. 
The high value of Seljugs, that replacing arabs, to the science and culture, was the reason of formation of a new school of poetry, that was founded by Sheikh Nizami in Ganja.

Historic and ethnographic exploration of problems and branches of crafts is very important, as a way of studying along with history and culture of the people, years generated political-economical and relations of production. Research of traditional wares of handicraft kinds of Ganja on the basis of innovative methods is very important and necessary. During our researches in 2012-2013 years we determined some new scientific arguments and facts in this field. The increase in quantity of handicraftsmen in a city directly has been bundled to population growth. Closely bundled to an economy and a daily life of the people, craft employment were one of the basic carriers of national traditions. The competition of production of production plants and factories has not reached still serious level and consequently was created a favorable condition for spreading of traditional occupations there. In addition, products of these craft branches have been closely bundled to a life and traditions of the people, and it would be difficult to replace with their factory production [Guliyeva, N.M., and Hasanov, E.L. 2013]. In the specified period of history in Ganja developed basically carpet weaving, weaver's business, craft of the tailor, squeeze men, forge and a jeweler, trades of dyer, the stone mason, the cooper and leather dresser, weapon business and other similar craft branches. Among these crafts especially developed carpet weaving. To so wide development of carpet weaving promoted availability of raw materials. In addition carpets were very widely used in a population life-both as furniture, and as a curtain, both as sand bed and as a coating for a floor. In carpet weaving have been held basically women. It has been bundled by that in a Muslim society of the woman preferred to work in house conditions. However also know cases when men were occupied with this craft.

\section{Materials and methods}

a) Tailors and hatters created both national clothes, and clothes in style of the European fashion. According to the spent explorations there are exact data on wide development of a jeweler in Ganja in the end of XIX century - in a beginning of XX centuries. Jewelers basically fabricated ornaments to order. Among them there was a specification. Jobs of skilful masters amazed even foreigners. Development of trading and economic relations of Ganja with the next states promoted recognition of local jewels abroad [Hasanov, E.L. 2014].

b) From the point of view silkworm breeding development and it's preparing technology there were two main forms of production: so-called raw silk weaving and felt weaving. In this important technological processes it has such kind of production stages as cocoon opening, silk initial processing, preparing of raw silk, weaving technology, painting and decoration. In the ancient Ganja during the stage of the Middle Ages the great progress of silkworm was represented by raw silk weaving. For this reason, on the basis of local traditions production of delicate silk textiles from raw silk. We must pay attention to the moment that differs from the other silk fabrics, kelaqai was prepared by specialists. But distinctly of production of raw silk that was city silkworm breeding and was man activity, felt production was woman work. In Ganja, that know as the ancient cultural center, the saddle-making handicraft differed from others with rich old traditions. First time preparation of the vehicles was house profession. But afterwards saddle preparation needed of qualified skilled masters, so a new type of art saddle-making, started to form. Historically the traditional art of saddle-making in Ganja developed in direction of cargo and passenger saddle making. The art of saddle-making within the local saddle-types and their components were determined on a specialization. The production of cargo or pack-saddle a rule was engaged by packsaddle maker. For this reason, in most cases, the profession was called trade of pack-saddle maker.

c) All the glass dishes found in and around Ganja are similar with the local clays on decoration of that period. Glass dishes were containing of Iron, cobalt, magnesium and other elements, that were specific elements for Ganja and its surroundings. The development history of this sphere of craftsmanship can be determined only through archaeological research. In general, information about the development of this sphere of was found in 19591960 years, glass products in and around Ganja was obtained only at the end of the twentieth century.

d) On a ground classifying crafts it has been defined that by the end of XIX century a number of fashionable trades began to disappear. Among them were wool-carder, hatcheller, selsbchy, dhulfachy, carriers. They have got rid of and have been replaced by representatives of new crafts [Ahmadov, F. 2007].

\section{Results}

Along with the works and notes of medieval authors and travelers, a lot of material samples, found in the territory of ancient Ganja, also found in Mingachevir and concern to Middle Ages trough, ladle, wooden threshing board, shows that in Ganja wood treatment and sculptor art have a rich tradition. Wood treatment products historically have been represented in various fields of social and cultural life in Ganja as the kitchen appliances: trough, quadruped, rolling-pin, mortar and pestle, ladle, spoon, trough, also transport means: sleigh, car, and 
ski. Weaving tools: comb, face. Household tools: harrow, wooden plow, threshing board, spade, wooden shouvel, pitchfork and rake. Musical instruments: saz, ud, tar, chamahcha, tambourine, drum [Hasanov, E.L. 2014]. The craftsmanship of carpet-making is one of the important cultural achievements of the Eastern people in Azerbaijan production of carpets appeared during I millennium BC. But carpet-making in the first period of Middle Ages has turned to the independent sphere of craft. In Ganja, that has minimum 4000 years history, production of carpets differed with quickly development. In this ancient city, that is native land of great Azerbaijani poet and thinker Sheikh Nizami Ganjavi, were weaved very uncial, inimitable kinds of carpet. In Ganja, that has rich traditions, were prepared carpets with various characteristics. For this reason one of Azerbaijani carpet groups are Ganja carpets [The dawn of Art. 1974]. These carpets that are producing by local inhabitants are differing with specific handicraft features. Majority of local wool products, richness of natural colors and existence professional carpet-making women made for quick development carpet making craftsmanship in Ganja and in its surround territories.

Just only in 1845 year there were produced 2969 carpets in Ganja. Among them products of 1784 manats have been exported. Also, from Ganja province there were exported 23 thousand pod in 1886,30 thousand 275 pod in 1889,33 thousand 156 pod in 1893, and 37 thousand 228 pod in 1913 carpets by railway. One part of these qualitative Ganja carpets has been transported with Batumi part top Turkey to Istanbul, and from there to West Europe and North America.

In whole at the beginning of XIX- XX century the quality of carpet craftsmen were more than $\mathrm{XX}$ thousand. Such kind of carpets without pile as phalas, kilim, holdall, bead, verni, sumach, heybe, carpet - bag were different with qualities and colored ornamental elements. Especially we must say that Ganja carpets have always been valued for its quality and art characteristics. As the result of in XIX - XX centuries most of Ganja carpets were showed in world in fluent exhibition. Nowadays, Ganja's carpets are kept in authoritative museums of world, and also in collection of different people. The studying of Ganja's carpets for art characteristics quality form science point of view is very important for investigation heritage of world culture [Hasanov, E.L. 2015b].

Made of precious metals gold and silver jewelries, that prepared by Ganja masters, are divided into 4 main groups for wearing and putting: Neck jewelries - it is included such kind of jewelries, that gold piece coin, imperial, cardamom or barley, medallions, bracelets, different kinds of beads and etc., jewelries for arms and fingers - this group include bracelets, bangles and rings with various precious stones as (turquoise, rubies, pearls and etc.), head jewelries - skull-cap and others, jewelries for clothiers [The dawn of Art. 1974]. From the construction point of view, samples of pottery, that concern to Antique period, also to the period of Hellenism in Ganja, differed in various forms as pictorial vases, ceramic figures, connected dishes. During the end of Middle Ages and New Period in Ganja and its regions ceramic has following kinds as building ceramic materials, unglazed ceramic products, glazed ceramic products. For Middle Ages and New period among pottery products of Ganja ceramic samples as clay construction materials have great importance. First of all, glazed bricks that used in construction of most buildings in the XVII-XVIII centuries, and also in great monuments and the main construction material - air-dried bricks, attracted attention. In addition to the found samples in residential areas as a result of archaeological excavations, also were found a lot of brick spoilages. According to such kind mass finding of brick spoilages, we can make the conclusion, that the bricks used in construction of buildings in Ganja, were wares of local production [Ahmadov, F. 2007].

The formation of pottery on the territory of ancient Ganja is concern to the stages of ancient history. Basis on research works carried out by the various persons in XIX century and expertsarcheologists at the beginning of XX century in old ruins of the city and surrounding areas there were found different samples of pottery. In the first half of the XVIII-XIX centuries, as well as in other parts of Azerbaijan, in Ganja household objects, forging weapons and jewelries that made from metal were decorated with different technical ways. As in many places, production of wool, cotton and silk in and around Ganja made necessary emergence and development of weaving. Becoming weaving one of the ancient spheres of crafts in and around Ganja was connected with the rich raw material base here. Presence of useful plant species for textile, including cotton, high level development of wool area of agriculture-sheep and goat breeding, camel breeding, horse breeding, presence of cotton cropping in Middle Ages and finally, regular expansion of silkworm breeding in this area created a foundation for growth of weaving here. In addition, during the research work in Ganjabasar and other territories monuments there have been found whole and parts of weaving loom and different sizes of clay and bone samples that consist to weaving. Traditional spheres of crafts are invaluable and reliable sources of studying of culture, aesthetic taste, outlook (world outlook) of the Azerbaijan people.

\section{Discussion}


1. Investigation of the main traditional craft branches on the basis of new, innovative methods and technologies is very important. Results of these researches show the significance of different patterns of craftsmanship kinds as a source in studying of historical past of nations.

2. Studying of craft problems actually and in the modern world in sense of the decision of professional problems. From the investigated national employment carpet weaving, the jeweler, a stone dressing and strenuously develop on the basis of ancient traditions already dying out ancient trades, such as a pottery and an art embroidery. Each area of Azerbaijan possesses characteristic environmental resource bases for it and it promoted development of various crafts. Thus, a number of employments in Ganja, during the period since XIX century to the middle of XX century, differed from crafts of other areas of the country. It was first of all the trades bundled to a spreading of a city and population grown has increased demand for craft products. Under such circumstances the handicraft work could not keep the natural character [Ahmadov, F. 2007].

3. In traditional production of cloth manufactory trade historically played an important place. This kind of craft that developed on the basis of local raw materials was tied with cotton-growing economy. Since the time of the early Middle Ages, Ganja as other big cities has been the main center of Azerbaijan in production of cotton cloth. In this ancient city printed cotton and calico fabrics have been widely produced. In traditional cloth productions the main place took the urban mines.

4. Internal conditions of craft department reflected a sort of employment of his owner. In these departments worked the master and his pupils. In a life of the population of Ganja the role of craft products was great. These products were widely used inhabitants of Ganja they decorated conditions of living rooms, with them filled up a dowry of brides. The dresses created in local departments, suits and caps were an integral part of an attire of towndwellers. In comparison with villages though the national clothes in XX century began to supersede them gradually. It also has been bundled to accruing arrival to Ganja representatives of other nationalities. Therefore changes in clothes were more marked. Only female ornaments as an attire constituent part left the national feature. At this time there were fashionable ornaments on a breast, hands, set pins and on clothes [Guliyeva, N.M., and Hasanov, E.L. 2013].

\section{References:}

1. Bünyadova ST (1992) Nizami və etnoqrafiya. Bak1: Elm.

2. Burton-Brown $\mathrm{T}$ (1951) Excavations in Azerbaijan, 1948. London.

3. Ohmədov FM (2007) Gəncənin tarix yaddaşı. Gəncə: Elm.

4. Ofəndiyev RS (1966) Azarbaycanin badii sənətkarlı̆̆l. Bakı: Azərnəşr.

5. Guliyeva NM, Häsänov EL (2014) Die traditionelle Gändschänischen Teppiche von Zeitraum der Aserbaidschanischen Gelehrten und Dichter Mirsä Schäfi Waseh als ethnoanthropologische quelle (XIX Jahrhundert). European Applied Sciences, 2: 3-5.

6. Hasanov EL (2014) Approccio innovativo per lo studio scientifico delle tradizioni artigianali grandi Ganja seconda metà del XIX-inizi XX secolo. Italian Science Review, 4: 642-645.

7. Hasanov EL (2014) Innovative basis of research of local handicraft branches of Ganja of the second half of XIX - beginning of XX centuries. Mediterranean Journal of Social Sciences, vol. 5, № 23, Part IV, pp. 2359-2362.
8. Hasanov EL (2014) To the question on the research of typical features of craftsmanship heritage of Ganja of the late XIX - early XX centuries. ISJ Theoretical \& Applied Science 12(20): 27-30. doi: http://dx.doi.org/10.15863/TAS.2014.12.20.7

9. Hasanov EL (2014) Basic craftsmanship branches of Ganja of the second half of XIX beginning of XX centuries as a historicethnographical source. 社会科学と人文科学のアジアジャーナル. 大山、日本. (Asian Journal of Social Sciences \& Humanities), vol. 3, Number 3, pp. 9-14.

10. Hasanov EL (2015a) Multidisciplinary approach to investigation of the basic handicraft branches of Ganja till the XX century. ISJ Theoretical \& Applied Science 1(21): 7-15. DOI:

http://dx.doi.org/10.15863/TAS.2015.01.21.2

11. Hasanov EL (2015b) To the Question on Research of Craftsmanship Traditions of Ganja of XIX - First Half of XX Centuries. Mediterranean Journal of Social Sciences, vol. 6, № 1, Part S1, pp. 433-437. 
12. Həmidova İ (2000) Azərbaycan parça sənətinin tarixi inkişaf yolları. Elmi axtarışlar, VIII toplu, Bak1.

13. Həvilov HA (1991) Azərbaycan etnoqrafiyast. Bakı: Elm.

14. Nishiaki Y, Hasanov EL (2014) About ethnoarchaeological and anthropological research of some prehistoric monuments of Ganja. ISJ Theoretical \& Applied Science, 1: 45-48. doi: http://dx.doi.org/10.15863/TAS.2014.01.9.8
15. Smith WB, Hasanov EL (2013) Importance of handicraft traditions in investigation of history of urban culture in Ganja. ISJ Theoretical \& Applied Science 11(7): 61-66. doi: http://dx.doi.org/10.15863/TAS.2013.11.7.10

16. Torlanov M, Ofəndiyev R (1960) Azarbaycan xalq sənəti. Bakı: Uşaq gənc nəşr.

17. The dawn of Art (1974) Leningrad: Aurora Art Publishers. 